\title{
Caries Removal
}

National Cancer Institute

\section{Source}

National Cancer Institute. Caries Removal. NCI Thesaurus. Code C52571.

Any process by which decayed tooth material is removed from the tooth. 